\title{
IbM PENGUNAAN SISTEM INFORMASI AKUNTANSI DALAM PENGOLAAN KEUANGAN USAHA WARUNG MAKAN KELURAHAN BAHU
}

\author{
Hisky Ryan Kawulur \\ Fakultas Ekonomi, Universitas Negeri Manado \\ kawulurhisky@yahoo.com
}

\begin{abstract}
The purpose of this IbM's is to improve the partner financial management capability in recording cash inflows and outflows transaction. The object of IbM are restaurants in Bahu district. The partners main problem are they never record any sales or purchase transaction in their bussiness, which is mean they don't know their net profit. Until July 2017 this IbM's had been implemented in throughthe solutions offered. The preparation, development, implementation and evaluation phases are the method that being used in this document. This IbM is success, right now partners had the capability to manage and improve their financial sector.
\end{abstract}

\section{Keywords: financial management, IbM, Cash Transaction}

\section{PENDAHULUAN}

Di Indonesia Usaha Kecil Menengah (UKM) merupakan pelaku bisnis yang bergerak pada berbagai bidang usaha yang menyentuh berbagai elemen masyarakat. UKM merupakan usaha yang terdapat di semua sektor ekonomi serta kagiatan yang membuka lapangan usaha tanpa harus mempunyai jenjang pendidikan yang tinggi maupun keahlian yang khusus, sehingga kontribusinya sangat besar terhadap Produk Domestik Bruto (PDB). Pada tahun 2013, jumlah UKM di seluruh Indonesia mencapai 56,5 juta dengan kontribusi kepada PDB sebesar 30\%. UKM merupakan sektor usaha yang paling banyak menyerap tenaga kerja di Indonesia hingga mencapai 90\% tenaga kerja Indonesia.

Melihat besarnya kontribusi pelaku UKM bagi kesejahteraan masyarakat secara luas, diperlukan perhatian dari semua pihak untuk lebih memajukan usaha UKM tersebut. Salah satu factor yang menjadi penentu keberhasilan organisasi adalah pengelolaan keuangan yang baik. Pengelolaan keuangan dengan menggunakan proses akuntansi akan membuat perusahaan mengetahui keseluruhan aktivitas ekonomi yang telah terjadi, informasi tentang penjualan dan pembelian barang atau jasa akan sangat gampang diketahui. Informasi yang tepat akan menimbulkan pengambilan keputusan yang tepat.

Sistem akuntansi akan memberikan beberapa manfaat bagi pelaku UKM, antara lain: (1) Menyediakan informasi ekonomis suatu perusahaan untuk pengambilan keputusan investasi dan kredit, (2) Memberikan gambaran kondisi perusahaan dari suatu periode ke periode berikutnya, (3) Memberikan potret yang dapat diandalkan mengenai kemampuan untuk menghasilkan laba, (4) Menjadi media komunikasi antar manajemen dengan pengguna informasi dan (5) Merupakan bentuk pertanggung jawaban manajemen.

Di manado sendiri mempunyai berbagai jenis UKM baik tempat foto-copy, warung, usaha persewaan, bengkel, dll. Terdapat beberapa masalah yang sama dalam perkembangan UKM di 9 kecamatan di manado (Wanea, Bunaken, Sario, Singkil, Malalayang, Wenang, Tikala, Mapanget dan Tuminting) termasuk wanea yaitu mereka belum pernah mendapat pelatihan bisnis dan pengelolaan baik segi keuagan atau produk, sehingga kegiatan usaha mereka belum bisa berkembang secara maksimal, Bappeda (2013).

Kelompok Warung makan didaerah Bahu, kecamatan Malalayang, kota Manado, 
terdiri dari 3 orang penusaha warung makan yang terletak di kompleks sekitaran kampus Unsrat. Target pemasaran dari warung ini adalah para mahasiswa dan orang kantoran yang bersekolah atau bekerja disekitaran kampus. Pada keseharian operasinya warung makan ini akan membeli bahan perlengkapan di pasar terlebih dahulu dan akan mengolahnya menjadi bahan makanan siap santap. Selama warung makan ini bediri dalam pembelian dan penjualannya belum pernah menggunakan proses pencatatan ataupun pembukuan. Dengan kondisi seperti ini para pengusaha warung makan tidak bisa mengetahui berapa laba yang sebenarnya terjadi dan biaya yang telah dikeluarkan selama operasinya dan akan berdampak pada pengambilan keputusan yang salah baik untuk ekspansi usaha, investasi atau kedit.

\section{METODE KEGIATAN}

Bertolak dari permasalahan masyarakat khususnya mitra maka solusi yang akan dilakukan adalah untuk menjawab permasalahan. Pertama,bagaimana meningkatkan kemampuan pemilik warung makan untuk mengelola biaya bahan baku dan biaya pengelolaan makanan, sehingga tersedianya informasi biaya yang akurat dalam memutuskan jumlah biaya produksi. Para pemilik warung makan tidak mempunyai kemampuan untuk mengklasifikasikan biaya apa saja yang terjadi selama pembuatan makanan dan tidak mempunyai kemampuan dalam menentukan jumlah biayanya. Kedua, bagaimana meningkatkan kemampuan pemilik warung makan untuk melakukan pengelolan laba operasi sehingga pemilik warung makan bisa memutuskan starategi ekspansi usaha yang baik, strategi investasi ataupun strategi pembayaran kredit. Dikarenakan tidak adanya pencatatan dan pembukuan maka pemilik warung makan tidak bisa menentukan aliran kas masuk atau keluar yang akan berdampak tidak adanya informasi yang akurat tentang pendapatan yang diterima. Ketiga adalah bagaimana meningkatkan kemampuan pemilik untuk mengevaluasi kinerja dari usahanya sehingga pemilik bisa menentukan apakah kinerja usaha itu baik atau buruk dan akan berdampak pada pemberian reward atau punishment kepada karyawan warung makan. Laporan keuangan merupakan salah satu bentuk pertanggung jawaban pihak karyawan kepada pemilik usaha, sehingga dari laporan tersebut akan terggambar apakan usaha ini mempunyai kinerja yang baik atau buruk.

\section{HASIL KEGIATAN DAN PEMBAHASAN}

Kegiatan IbM telah dilaksanakan sesuai dengan solusi yang ditawarkan kepada kelompok Mitra sampai pada bulan Juli 2017. Kegiatan ini dapat dikatakan berhasil seratus persen sebab telah terjadi peningkatan kemampuan pembukuan melalui pencatatan arus kas masuk melalui buku kas masuk serta pencatatan arus kas keluar melalui buku kas keluar dan penyusunan laporan keuagan sederhana. Pada awalnya mereka mengalami permasalahan yaitu tidak pernah mengetahui keuntungan dan pengeluaran harian ini dikarenakan belum pernah melakukan pencatatan dan pembukuan yang terformat atas pemasukan dan pengeluaran dari bisnis warung makan, tetapi dengan kegiatan IbM telah menghasilkan kemampuan pencatatan dan pembukuan yang baik sehingga mereka bisa melakukan pengambilan keputusan yang lebih akurat terkait dengan perencanaan keuangan usaha warung makan.

Kegiatan IbM ini telah mendorong kelompok Mitra menjadi lebih aktif dalam mengontrol, merencanakan dan mengelola keuangan usaha mereka. Pengeluaran sekarang bisa dikontrol dengan membandingkan rata-rata pengeluaran selama bebarapa hari. Pegawai yang ditugaskan untuk membeli bahan baku untuk makanan tidak bisa melakukan kecurangan atau penyimpangan dikarenakan pemilik memiliki catatan rata-rata pengeluaran per hari dan catatan berapa harga dari barang yang akan dibeli. Pemasukan atau penjualan yang telah dicatat dengan buku kas masuk memiliki nilai informasi untuk perencanaan keuangan usaha kelompok mitra misalnya ekspansi usaha, pembelian peralatan warung 
makan, penambahan karyawan, pengajuan kredit di bank dan masih banyak lagi kegunaannya. Laporan keuangan sederhana yang disusun yaitu laporan laba rugi dengan cara menghitung seluruh pemasukan usaha dan menguranginya dengan seluruh pengeluaran. Dengan adanya peningkatan pemahaman akan pencatatan transaksi usaha secara tidak langsung mengakibatkan pemilik warung makan mulai memikirkan strategi untuk pengembangan usaha dan kesuksessan usaha warung makan.

Untuk menjaga kontuinitas usaha dan lebih meningkatkan daya saing usaha maka kedepan perlu dibekali dengan pengetahuan manajemen sehingga terjadi pengelolaan usaha yang professional. Peningkatan variasi jenis makan juga perlu dilakukan sehingga konsumen tidak merasa bosan dengan menu makanan yang selalu sama.

\section{KESIMPULAN}

Melalui Program Iptek bagi Masyarakat (IbM) dapat disimpulkan bahwa kegiatan ini telah meningkatkan kemampuan pencatatan dan pengelolaan keuangan dari usaha warung makan mitra. Dengan adanya peningkatan pemahaman akan pencatatan transaksi usaha secara tidak langsung mengakibatkan pemilik warung makan mulai memikirkan strategi untuk pengembangan usaha dan kesuksessan usaha warung makan. Mitra sekarang telah memiliki pengetahuan untuk mengontrol pengeluaran dan mencegas kecurangan terkait pembelian barang, memiliki pengetahuan perencanaan laba dengan menginvestasikan sisa keuntungan untuk membuka cabang baru, menambah peralatan atau asset, dll.

\section{Saran}

Untuk menjaga kontuinitas usaha dan lebih meningkatkan daya saing usaha maka kedepan perlu dibekali dengan pengetahuan manajemen produksi dan marketing sehingga terjadi pengelolaan usaha yang lebih professional. Peningkatan variasi jenis makan juga perlu dilakukan sehingga konsumen tidak merasa bosan dengan menu makanan yang selalu sama.

\section{REFERENSI}

Niswonger, 2013. Pengantar Akuntansi jilid 1, Jakarta : Salemba Empat

Kieso \& Weygan, 2010. Pengantar Akuntansi 2, Jakarta: Salemba Empat 